\title{
Molecular mechanisms of calcium signaling in the modulation of small intestinal ion transports and bicarbonate secretion
}

\author{
Xin Yang ${ }^{1, *}$, Guorong Wen ${ }^{2, *}$, Biguang Tuo ${ }^{2}$, Fenglian Zhang ${ }^{1}$, Hanxing Wan ${ }^{1}$, Jialin \\ $\mathrm{He}^{1}$, Shiming Yang ${ }^{2}$ and Hui Dong ${ }^{1,3}$ \\ ${ }^{1}$ Department of Gastroenterology, Xinqiao Hospital, Third Military Medical University, Chongqing 400037, China \\ ${ }^{2}$ Department of Gastroenterology, Affiliated Hospital, Zunyi Medical College, and Digestive Disease Institute of Guizhou \\ Province, Zunyi 563003, China \\ ${ }^{3}$ Department of Medicine, School of Medicine, University of California, San Diego, CA 92093, USA \\ "These authors contributed equally to this work \\ Correspondence to: Hui Dong, email: h_uidong@163.com \\ Shiming Yang, email: 13228686589@163.com
}

Keywords: carbachol; $\mathrm{Ca}^{2+}$ signaling; SOCE; duodenal epithelial ion transports

Received: October 19, $2017 \quad$ Accepted: December 01, $2017 \quad$ Published: December 11, 2017

Copyright: Yang et al. This is an open-access article distributed under the terms of the Creative Commons Attribution License 3.0 (CC BY 3.0), which permits unrestricted use, distribution, and reproduction in any medium, provided the original author and source are credited.

\section{ABSTRACT}

Background and Purpose: Although $\mathrm{Ca}^{2+}$ signaling may stimulate small intestinal ion secretion, little is known about its critical role and the molecular mechanisms of $\mathrm{Ca}^{2+}$-mediated biological action.

Key Results: Activation of muscarinic receptors by carbachol(CCh) stimulated mouse duodenal $I_{\mathrm{sc}^{\prime}}$ which was significantly inhibited in $\mathrm{Ca}^{2+}$-free serosal solution and by several selective store-operated $\mathrm{Ca}^{2+}$ channels(SOC) blockers added to the serosal side of duodenal tissues. Furthermore, we found that CRAC/Orai channels may represent the molecular candidate of SOC in intestinal epithelium. CCh increased intracellular $\mathrm{Ca}^{2+}$ but not $\mathrm{CAMP}$, and $\mathrm{Ca}^{2+}$ signaling mediated duodenal $\mathrm{Cl}^{-}$and $\mathrm{HCO}_{3}{ }^{-}$ secretion in wild type mice but not in CFTR knockout mice. CCh induced duodenal ion secretion and stimulated PI3K/Akt activity in duodenal epithelium, all of which were inhibited by selective PI3K inhibitors with different structures. $\mathrm{CCh}$-induced $\mathrm{Ca}^{2+}$ signaling also stimulated the phosphorylation of CFTR proteins and their trafficking to the plasma membrane of duodenal epithelial cells, which were inhibited again by selective PI3K inhibitors.

Materials and Methods: Functional, biochemical and morphological experiments were performed to examine ion secretion, PI3K/Akt and CFTR activity of mouse duodenal epithelium. $\mathrm{Ca}^{2+}$ imaging was performed on HT-29 cells.

Conclusions and Implications: $\mathrm{Ca}^{2+}$ signaling plays a critical role in intestinal ion secretion via CRAC/Orai-mediated SOCE mechanism on the serosal side of epithelium. We also demonstrated the molecular mechanisms of $\mathrm{Ca}^{2+}$ signaling in CFTR-mediated secretion via novel PI3K/Akt pathway. Our findings suggest new perspectives for drug targets to protect the upper GI tract and control liquid homeostasis in the small intestine.

\section{INTRODUCTION}

Epithelial ion transports are critical physiological processes in the human gastrointestinal (GI) tract. Intestinal epithelium either absorbs electrolytes or secretes ions (such as $\mathrm{Cl}^{-}$and $\mathrm{HCO}_{3}^{-}$), which provides the driving force for water absorption or secretion to maintain the liquid homeostasis in the human body. Epithelial ion transports are under control of several neuro-humoral factors, including ACh, 5-HT, PGs, nitric oxide (NO), and capsaicin-sensitive afferent neurons [1]. These neuro-humoral factors mediate epithelial ion transports 
through three major cellular signaling: $\mathrm{Ca}^{2+}$, cAMP- and cGMP-dependent pathways. Among them, ACh is one of the major excitatory neurotransmitter in GI system. The chemical analogue of $\mathrm{ACh}$, carbachol (CCh), a muscarinic receptor agonist, is a commonly used $\mathrm{Ca}^{2+}$ mobilizer. Currently, the physiological roles and molecular mechanisms of cAMP- and cGMP-dependent regulation of epithelial $\mathrm{Cl}^{-}$and $\mathrm{HCO}_{3}{ }^{-}$secretion are relatively well defined; however, those mediated by $\mathrm{Ca}^{2+}$ signaling remain poorly understood in small intestinal epithelia [2].

Moreover, although it is known that $\mathrm{Ca}^{2+}$ signaling is critical for intestinal epithelial ion secretion [2], the underlying detailed mechanisms that control cytosolic $\mathrm{Ca}^{2+}$ concentration $\left(\left[\mathrm{Ca}^{2+}\right]_{\text {cyt }}\right)$ homeostasis in small intestinal epithelium are not fully understood [3]. It is generally thought that agonists induce $\mathrm{Ca}^{2+}$ signaling via two major processes in non-excitable cells: the $\mathrm{IP}_{3}$ induced release of $\mathrm{Ca}^{2+}$ from intracellular stores, and then an enhanced $\mathrm{Ca}^{2+}$ entry from the extracellular medium [4]. Classically, the $\mathrm{Ca}^{2+}$ entry in non-excitable epithelial cells was thought to occur mainly via so-called capacitative or store-operated $\mathrm{Ca}^{2+}$ channels (SOCs), which activation is entirely dependent on the depletion of intracellular $\mathrm{Ca}^{2+}$ stores $[5,6]$. These channels are the $\mathrm{Ca}^{2+}$-release activated $\mathrm{Ca}^{2+}$ channels (CRAC) first described in mast cells and Jurkat lymphocytes $[7,8]$, which are accomplished by the pore forming $\mathrm{Ca}^{2+}$ channel Orai $[9,10]$. However, only a few studies have focused on the role of CRAC/Orai channels in polarized epithelial cells, such as intestinal epithelial cell line IEC-6 cells [11] and colonic epithelial cells $[12,13]$. So far, the regulatory mechanisms of $\left[\mathrm{Ca}^{2+}\right]$ homeostasis in native epithelial cells of the small intestine are still unclear.

The major focus of $\mathrm{Cl}^{-}$and of $\mathrm{HCO}_{3}{ }^{-}$secretion in the small intestine is on cAMP- and cGMP-dependent regulatory pathways, which mediates several membrane ion channels to contribute to epithelial ion transports. The cystic fibrosis transmembrane conductance regulator (CFTR) is one of the critical channels in the luminal membrane of enterocytes [14]. CFTR is a cAMP/PKA and cGMP/PKG -dependent channel abundantly expressed in several functionally diverse tissues, such as the pancreas, intestine, kidney, sweat duct, and lung [15, 16]. In intestinal epithelial cells (IEC), it regulates $\mathrm{Na}^{+}, \mathrm{Cl}^{-}$, and $\mathrm{HCO}_{3}^{-}$transports [17]. Although CFTR is principally activated by cAMP/PKA and cGMP/PKG pathways, it is also regulated by $\mathrm{Ca}^{2+}$ signaling [18]. However, it is currently unclear for the detailed regulatory mechanisms of CFTR by $\mathrm{Ca}^{2+}$ signaling, particularly it is unknown if $\mathrm{Ca}^{2+}$ signaling per se is able to activate CFTR or is through potentiating cAMP/PKA-mediated CFTR activation.

The duodenal mucosa, due to its strategic location between the stomach and other segments of the small intestine, senses luminal nutrients and regulates duodenal epithelial ion transports, particularly $\mathrm{Cl}^{-}$and $\mathrm{HCO}_{3}^{-}$secretion, which in turn is important for nutrient absorption and mucosal protection from gastric acid [19]. Therefore, in the present study, we sought to investigate $\mathrm{Ca}^{2+}$ signaling mediated duodenal epithelial ion secretion and the underlying molecular mechanisms. We found that $\mathrm{CCh}$ stimulates extracellular $\mathrm{Ca}^{2+}$ entry likely through SOC/Orai channels mainly from the basolateral membrane of IEC. The increased $\left[\mathrm{Ca}^{2+}\right]_{\text {cyt }}$ per se is enough to trigger duodenal transepithelial secretion through a novel PI3K/ AKT/CFTR pathway. This study not only reveals that $\mathrm{Ca}^{2+}$ signaling is critical to activate CFTR-mediated epithelial ion transportsin the small intestine, but also provides novel insights into the detailed mechanisms of $\mathrm{Ca}^{2+}$-dependent transepithelial $\mathrm{Cl}^{-}$and $\mathrm{HCO}_{3}^{-}$secretion.

\section{RESULTS}

\section{Activation of muscarinic receptors induced intracellular $\mathrm{Ca}^{2+}$ release and extracellular $\mathrm{Ca}^{2+}$ entry}

We applied $\mathrm{CCh}$, a muscarinic receptor agonist, to mobilize intracellular $\mathrm{Ca}^{2+}$. CCh $(100 \mu \mathrm{M})$ markedly increased duodenal short-circuit current $\left(I_{\text {sc }}\right)$ (Figure 2A), which was attenuated by atropine $(10 \mu \mathrm{M})$, a muscarinic receptor antagonist (Supplementary Figure 1A). Activation of muscarinic receptors stimulates the production of inositol 1,4,5-trisphoshate ( $\mathrm{IP}_{3}$ ), leading to intracellular $\mathrm{Ca}^{2+}$ release via IP3 receptors on the endoplasmic reticulum (ER) membrane [20]. We used $\mathrm{LiCl}(30 \mathrm{mM})$ to inhibit $\mathrm{IP}_{3}$ production and confirmed the involvement of $\mathrm{IP}_{3}$ pathway in the process of muscarinic receptorsmediated intracellular $\mathrm{Ca}^{2+}$ release (Supplementary Figure 1B).

To further test if intracellular $\mathrm{Ca}^{2+}$ release mediates extracellular $\mathrm{Ca}^{2+}$ entry into IEC, CCh-stimulated duodenal $I_{\text {sc }}$ was compared in the presence or the absence of extracellular $\mathrm{Ca}^{2+}$ in each side of the Ussing chamber experiments. As shown in Figure $1 \mathrm{~A}$ and $1 \mathrm{~B}, \mathrm{CCh}-$ stimulated duodenal $I_{\mathrm{sc}}$ was significantly attenuated when extracellular $\mathrm{Ca}^{2+}$ was omitted from the serosal side of the duodenal tissues, but not from the mucosal side. Moreover, CCh-stimulated duodenal $I_{\text {sc }}$ was not significantly different between $\mathrm{Ca}^{2+}$ omissions from the serosal side only and from both sides of the tissues (Figure 1B). Therefore, $\mathrm{CCh}$ may induce intracellular $\mathrm{Ca}^{2+}$ release that further mediates extracellular $\mathrm{Ca}^{2+}$ entry from the serosal side of the duodenal epithelium.

\section{CCh induced SOCE mechanism on the serosal side of the duodenal epithelium}

It is well known that intracellular $\mathrm{Ca}^{2+}$ release to deplete the $\mathrm{Ca}^{2+}$ store in the ER would promote extracellular $\mathrm{Ca}^{2+}$ entry, which is the so-called storeoperated $\mathrm{Ca}^{2+}$ entry (SOCE). Because it is still uncertain for the functional expression of the voltage-operated $\mathrm{Ca}^{2+}$ 
channels in small intestinal epithelia, it is believed that SOCE fulfill this function [21]. To test if this mechanism occurs in duodenal epithelium, we used three selective SOCE blockers with different chemical structures. As shown in Figure 2A, addition of 2-Aminoethoxydiphenyl borate $(2-\mathrm{APB})(50 \mu \mathrm{M})$ to the mucosal side of the duodenal tissues did not affect the time course of CChstimulated duodenal $I_{\mathrm{sc}}$, but addition to serosal side significantly suppressed the duodenal $I_{\mathrm{sc}}$. Figure 2B summarizes the effect of 2-APB on duodenal $I_{\mathrm{sc}}$ peak after it was added to each side of the duodenal tissues. Similar to $2-\mathrm{APB}$, both Flufenamic acid (FFA) $(100 \mu \mathrm{M})$ and SKF$96365(30 \mu \mathrm{M})$ significantly suppressed duodenal $I_{\text {sc }}$ peak from serosal side of the duodenal tissues, but not from the mucosal side (Figure 2C and 2D). Therefore, SOCE mechanism occurs exclusively on the serosal side of the duodenal epithelium, which is consistent with the previous findings described above.

\section{CRAC/Orai channels in the regulation of $\mathrm{CCh}$ - stimulated duodenal $I_{\mathrm{sc}}$}

We screened the molecular candidates of SOCE in duodenal epithelium. We first examined common $\mathrm{Ca}^{2+}$ permeable channels, such as TRPV1, TRPV4 and NCX using their selective blockers AMG-517 (100 $\mu \mathrm{M}), \mathrm{RN}-$ $1734(30 \mu \mathrm{M})$ and KBR-7943 $(30 \mu \mathrm{M})$, respectively. As shown in Figure 1C, 1D and 1E, addition of them to the serosal side did not alter CCh-induced duodenal $I_{s c}$, indicating no functional expression of TRPV1, TRPV4 and NCX to exclude them as the molecular candidates of SOCE in duodenal epithelium.

We further identified the molecular candidates of SOCE using GSK-7975A, a specific CRAC/Orai channel blocker. As shown in Figure 2E, addition of GSK$7975 \mathrm{~A}(100 \mu \mathrm{M})$ to serosal side of the duodenal tissues significantly suppressed the time course of CCh-stimulated
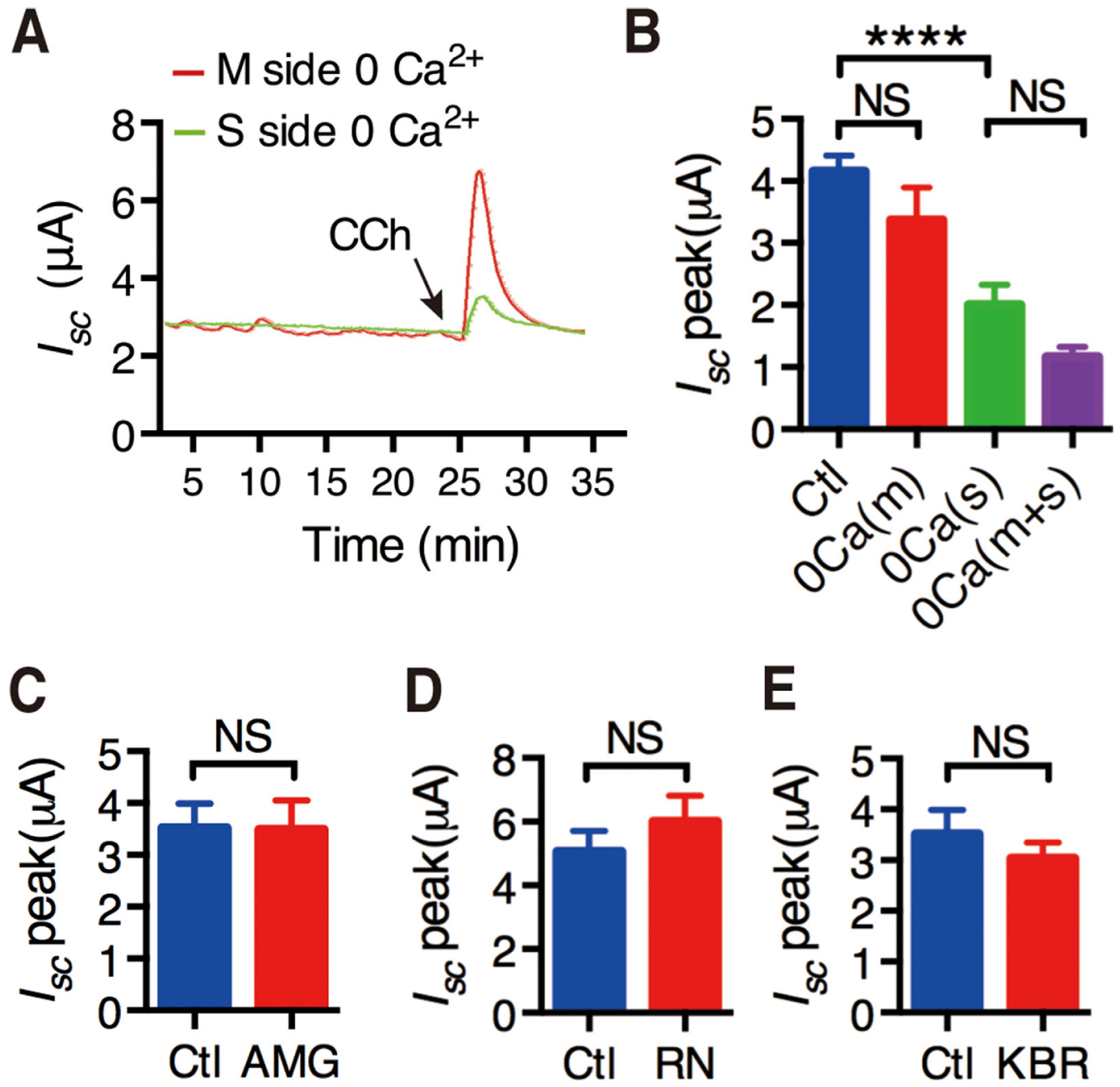

Figure 1: Activation of muscarinic receptors induced extracellular $\mathrm{Ca}^{2+}$ entry through possible pathways. (A) Representative of the time course of CCh-stimulated murine duodenal mucosal $I_{\text {sc }}$ after extracellular $\mathrm{Ca}^{2+}$ was omitted from the serosal side or the mucosal side of the duodenal tissues. (B) The summary data of CCh-stimulated duodenal $I_{\mathrm{sc}}$ peak after $\mathrm{Ca}^{2+}$ omission from the mucosal side, the serosal side or both sides of duodenal tissues. (C-E) Effects of AMG-517 (AMG, 100 M) (C), RN-1734 (RN, 3 M) (D) and KBR-7943(KBR, 3 M) (E) on CCh-induced duodenal $I_{\text {sc }}$ peak after serosal addition. Results are presented as mean SE $(n=6-9$ in each series). NS, no significant differences, ${ }^{* * * *} P<0.0001 v$ s. control by Student's $t$-test. 
duodenal $I_{\text {sc }}$. Figure $2 \mathrm{~F}$ summarizes the inhibitory effect of GSK-7975A on duodenal $I_{\text {sc }}$ peak after it was added to serosal side. Therefore, CRAC/Orai channels may represent the molecular candidate of SOCE in duodenal epithelium.

\section{CRAC/Orai channels in CCh-mediated $\mathrm{Ca}^{2+}$ entry into IEC}

Since HT-29 cell line is commonly used as a cell model of IEC to study ion absorption and secretion [22$24]$, and they express the muscarinic receptor [12, 25, 26], we used them to measure $\left[\mathrm{Ca}^{2+}\right]_{\text {cyt }}$ by digital $\mathrm{Ca}^{2+}$ imaging. $\mathrm{CCh}(100 \mu \mathrm{M})$ immediately induced $\mathrm{Ca}^{2+}$ signaling in HT29 cells (Figure 3A). 2-APB (50 $\mu \mathrm{M})$ and GSK-7975(30 $\mu \mathrm{M}$ ) almost abolished $\mathrm{CCh}$-induced $\mathrm{Ca}^{2+}$ signaling (Figure $3 \mathrm{~B}$ and $3 \mathrm{C}$ ). Both peak and the rising slope of $\mathrm{CCh}-$ induced $\left[\mathrm{Ca}^{2+}\right]_{\text {cyt }}$ signaling were significantly decreased by 2-APB and GSK-7975 (Figure 3D and 3E).

We further examined the role of CRAC/Orai channels in SOCE mechanism. In HT-29 cells superfused with $\mathrm{Ca}^{2+}$-free solution (0Ca) first caused a rapid increase in $\left[\mathrm{Ca}^{2+}\right]_{\text {cyt }}$ due to intracellular $\mathrm{Ca}^{2+}$ release from the ER to the cytosol (Figure 3F, left). After $\mathrm{Ca}^{2+}$ release from the ER was complete, restoration of extracellular $\mathrm{Ca}^{2+}(2 \mathrm{Ca})$ caused an additional increase in $\left[\mathrm{Ca}^{2+}\right]_{\text {cyt }}$ due to SOCE mechanism (Figure 3F, right). As shown in Figure $3 \mathrm{G}$ and H, GSK-7975A (30 $\mu \mathrm{M})$ significantly inhibited CChinduced SOCE mechanism. Therefore, these data further support our previous notion that CRAC/Orai channels are the molecular candidate of SOCE in IEC.

\section{Role of CFTR channels in CCh-induced epithelial ion secretion}

First, to test if $\mathrm{CCh}$-induced $\mathrm{Ca}^{2+}$ signaling could stimulate duodenal $I_{\text {sc }}$ through $\mathrm{Ca}^{2+}$-activated $\mathrm{Cl}^{-}$channels (CaCC), we applied commonly used $\mathrm{CaCC}$ blocker niflumic acid (NFA). At the concentrations of 100-300 $\mu \mathrm{M}$, it did not affect CCh-induced duodenal $I_{\text {sc }}$ (Figure 4A). Furthermore, $\mathrm{T}_{16 \mathrm{~A}_{\mathrm{inh}}} \mathrm{A}$ - $1(300 \mu \mathrm{M})$, a selective potent CaCC blocker did not affect $\mathrm{CCh}$-induced duodenal $I_{s c}$ either (Figure 4B). These results exclude the role of $\mathrm{CaCC}$ in the CCh-induced duodenal epithelial ion secretion.

Second, we examined the role of CFTR channels in this process since they are critical in epithelial ion secretion stimulated by several secretagogues. As shown in Figure $4 \mathrm{C}$ and 4D, CFTR $_{\text {inh }}-172(30 \mu \mathrm{M})$, a highly potent and specific CFTR inhibitor [27], markedly inhibited CChinduced duodenal $I_{\text {sc }}$. Further, we applied CCh to $\mathrm{CFTR}^{+/+}$ and $\mathrm{CFTR}^{-/}$mice, and found that CCh markedly stimulated duodenal $I_{s c}$ and $\mathrm{HCO}_{3}^{-}$secretion in $\mathrm{CFTR}^{+/+}$mice (Figure $4 \mathrm{E}$ and $4 \mathrm{~F}$ ). However, $\mathrm{CCh}$ failed to induce duodenal $I_{s c}$ and decreased duodenal $\mathrm{HCO}_{3}^{-}$secretion in $\mathrm{CFTR}^{-/}$ mice. The net peak of $\mathrm{CCh}$-stimulated duodenal $\mathrm{HCO}_{3}^{-}$ secretion was reduced by $61 \%$ and the net peak of duodenal $I_{s c}$ was reduced by $99 \%$, respectively in CFTR - mice (Figure 4E and 4F). We therefore underscored the critical role of CFTR channels in CCh-induced $\mathrm{Ca}^{2+}$ mediated duodenal ion secretion.

\section{CCh-induced duodenal ion secretion was cAMP/ PKA-independent}

Since $\mathrm{Ca}^{2+}$ signaling is able to activate CFTRmediated ion secretion through cAMP/PKA pathway in other epithelial tissues, we tested this notion in CChinduced duodenal epithelial ion secretion. We first determined if there is a cross-talk between $\mathrm{Ca}^{2+}$ and cAMP signaling in the activation of CFTR channels. When low concentrations of cAMP-generating agonist forskolin( $(0.15$ $\mu \mathrm{M})$ and $\mathrm{CCh}(30 \mu \mathrm{M})$ were added together, a synergistic effect on duodenal $I_{s c}$ was observed (the green line and bar in Supplementary Figure 2A and 2B). However, this synergistic effect was not affected by the pretreatment of $\mathrm{H} 89(20 \mu \mathrm{M})$, a commonly used PKA inhibitor (Supplementary Figure 2D-2F).

To exclude the role of cAMP/PKA pathway in CChinduced duodenal ion secretion, we directly measured cAMP activity. As shown in Supplementary Figure 2C, CCh $(100 \mu \mathrm{M})$ did not alter cAMP concentration in mouse duodenal epithelium, but forskolin $(10 \mu \mathrm{M})$ markedly increased it. These results further confirm that $\left[\mathrm{Ca}^{2+}\right]_{\text {cyt }}$-mediated duodenal ion secretion is cAMP/PKAindependent although a synergy exists between these two signaling pathways.

\section{PI3K/Akt in CCh-induced duodenal ion secretion}

Growing evidence suggest that CFTR channels can be activated by $\mathrm{Ca}^{2+}$-dependent PKA, PKC and tyrosine kinase in different epithelial tissues [28]. Here we examined if PI3K/Akt is involved in CCh-induced duodenal ion secretion. As shown in Figure 5A-5D, both selective PI3K inhibitors, wortmannin $(0.1 \mu \mathrm{M})$ and LY294002 $(20 \mu \mathrm{M})$, which have been shown to target PI3K activity at these concentrations [29, 30] significantly reduced CCh-stimulated mouse duodenal $\mathrm{HCO}_{3}{ }^{-}$secretion and duodenal $I_{s c}$. Wortmannin reduced net peak of CCh-stimulated duodenal $\mathrm{HCO}_{3}{ }^{-}$secretion by $49 \%$ and duodenal $I_{s c}$ by $42 \%$, respectively (Figure $5 \mathrm{~A}$ and 5B). LY294002 reduced net peak of CCh-stimulated duodenal $\mathrm{HCO}_{3}^{-}$secretion by $23 \%$ and duodenal $I_{s c}$ by $43 \%$, respectively (Figure 5C and 5D).

To confirm the role of $\mathrm{PI} 3 \mathrm{~K}$ in the regulation of CFTR function, PI3K activity in duodenal epithelium was measured. CCh $(100 \mu \mathrm{M})$ rapidly stimulated PI3K activity and reached the peak within 1 min (Figure 5E). $\mathrm{CCh}$ induced the maximal PI3K activity by 4.5 -fold compared with basal levels. Subsequently, we further examined whether $\mathrm{CCh}$ induces phosphorylation of Akt, 

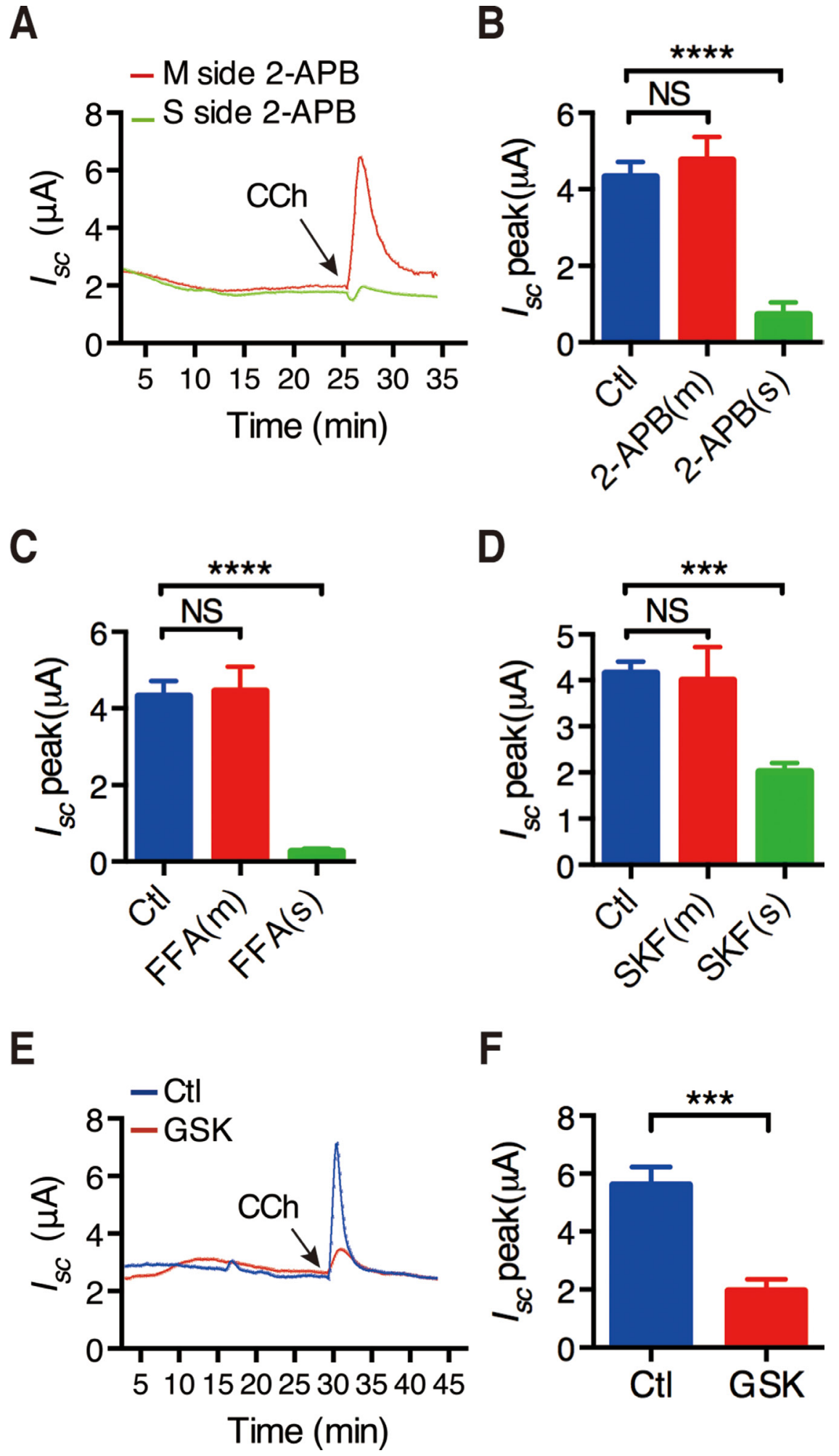

Figure 2: CRAC/Orai channels in the regulation of $\mathbf{C C h}$-stimulated duodenal $\boldsymbol{I}_{\text {sc }}$ (A) Representative of the time course of $\mathrm{CCh}$-stimulated murine duodenal $I_{\text {sc }}$ with or without addition of 2-aminoethoxydiphenyl borate (2-APB, $\left.50 \mathrm{M}\right)$ to the mucosal or serosal side of duodenal tissues. (B) The summary of the effect of 2-APB on CCh-stimulated murine duodenal $I$ se peak after mucosal or serosal addition. (C-D) Summery effects of the flufenamic acid (FFA, 100 M) (C) or SKF-96365 (SKF, 3 M) (D) on CCh-stimulated duodenal $I_{\text {sc }}$ peak after mucosal or serosal addition. (E) Representative of the time course of CCh-stimulated duodenal $I_{\text {sc }}$ with or without serosal addition of GSK-7975A (GSK, $100 \mathrm{M})$. (F) The summary of the effect of GSK-7975A on CCh-stimulated duodenal $I_{\text {sc }}$ peak after serosal addition. Results are presented as mean SE $\left(n=6-9\right.$ in each series). NS, no significant differences, ${ }^{* * *} P<0.001,{ }^{* * * *} P<0.0001 v s$. control. 

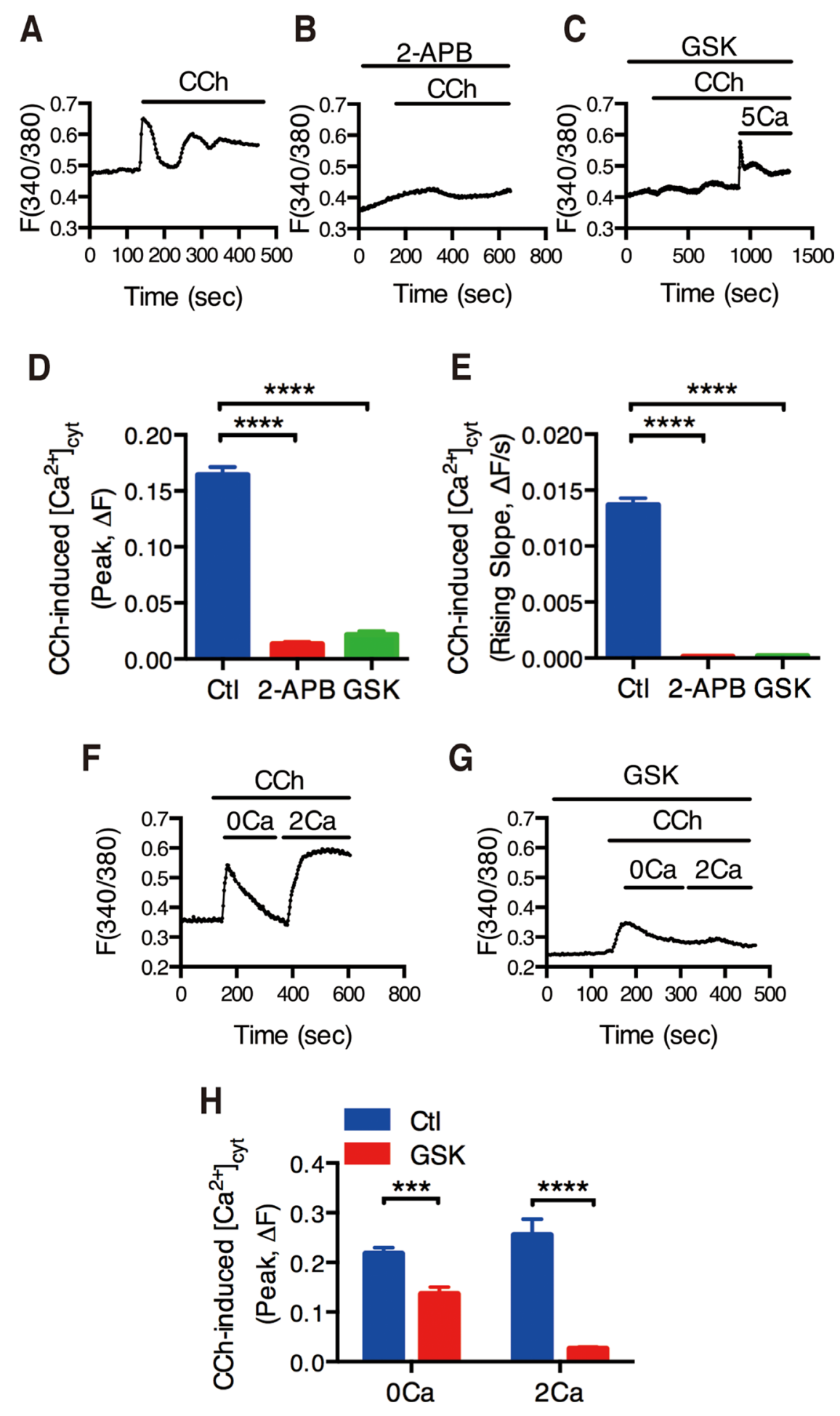

Figure 3: Functional identification of CRAC/Orai channels in CCh-mediated $\mathrm{Ca}^{2+}$ mobilization of intestinal epithelial cells. (A) Time courses showing the effect of CCh $(10 \mathrm{M})$ on basal $\left[\mathrm{Ca}^{2+}\right]_{\text {cyt }}$ of human colon carcinoma HT-29 cells in normal physiological salt solutions. (B-C) Time courses showing the effect of 2-APB (5 M, B) or GSK-7975A (GSK, 3 M, C) on CCh-mediated $\left[\mathrm{Ca}^{2+}\right]_{\mathrm{cyt}}$ mobilization in HT-29 cells. (D-E) The summary of the effect of 2-APB or GSK on the peaks (D) and the rising slopes (F) of CCh-induced $\left[\mathrm{Ca}^{2+}\right]_{\text {cyt }}$ signaling in HT-29 cells. (F) Time courses showing CCh $(10 \mathrm{M})$ first caused a rapid increase in $\left[\mathrm{Ca}^{2+}\right]_{\text {cyt }}$ when HT-29 cells was superfused with $\mathrm{Ca}^{2+}$-free solution ( $\left.0 \mathrm{Ca}\right)($ left $)$. After $\mathrm{Ca}^{2+}$ release from the ER was complete, restoration of extracellular $\mathrm{Ca}^{2+}(2 \mathrm{mM} \mathrm{Ca})$ caused an additional increase in $\left[\mathrm{Ca}^{2+}\right]_{\text {cyt }}$ in HT-29 cells $(r i g h t)$. (G) Time courses showing the effect of GSK-7975A (GSK, 3 M) on CChinduced $\left[\mathrm{Ca}^{2+}\right]_{\text {cyt }}$ mobilization in HT-29 cells superfused with $\mathrm{Ca}^{2+}$-free solution $(0 \mathrm{Ca})$ or $\mathrm{Ca}^{2+}$-containing solution (2 Ca). (H) Summary data on the effect of GSK-7975A on CCh-induced $\left[\mathrm{Ca}^{2+}\right]_{\text {cyt }}$ mobilization in HT-29 cells superfused with $\mathrm{Ca}^{2+}$-free solution (0 Ca) or Ca ${ }^{2+}-$ containing solution (2 Ca). Results are presented as mean SE $\left(n=20-30\right.$ cells). ${ }^{* * *} P<0.001,{ }^{* * * *} P<0.0001 v$ s. control or DMSO. 
a downstream effector of PI3K. Likewise, CCh caused a rapid phosphorylation of Akt. Notably, the time courses of CCh-stimulated PI3K activity and phosphorylation of Akt in duodenal epitheliumare matchable (Figure 5F). Again, both wortmannin and LY294002 significantly inhibited CCh-stimulated phosphorylation of Akt (Figure 5G). This direct evidence confirms the critical role of PI3K/Akt in CCh-induced $\mathrm{Ca}^{2+}$-mediated activity of CFTR channels.

\section{PI3K/Akt in CCh-mediated phosphorylation and translocation of CFTR channels}

The phosphorylation and translocation of CFTR channels to the surface of duodenal villus cells are important indicators of CFTR activity. To provide the confirmatory evidence for the role of PI3K in $\mathrm{Ca}^{2+}$ signaling mediated CFTR activation, we assessed CCh-
A

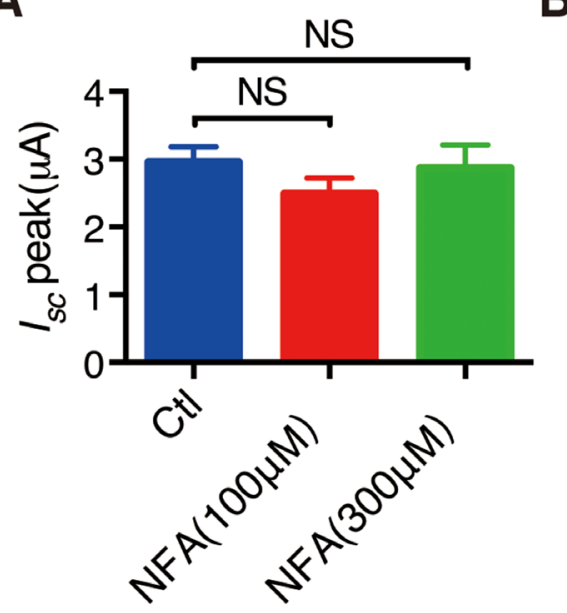

C

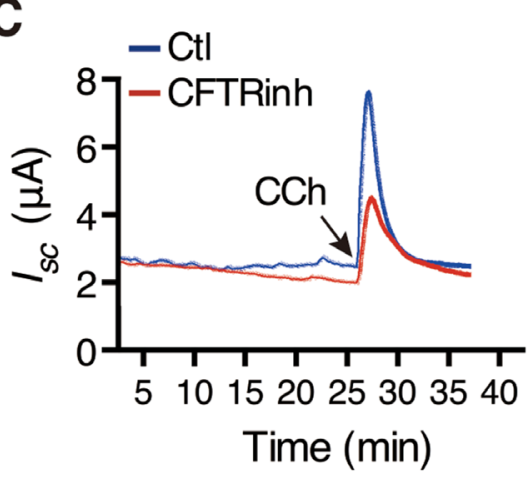

B

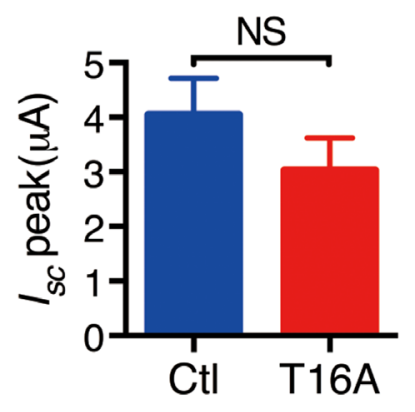

D

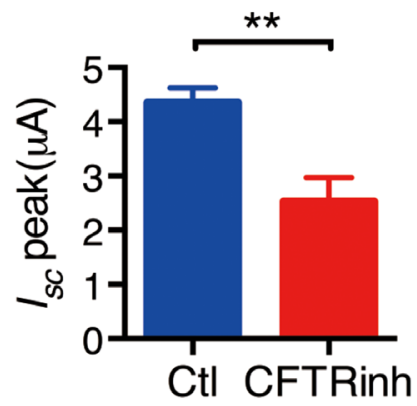

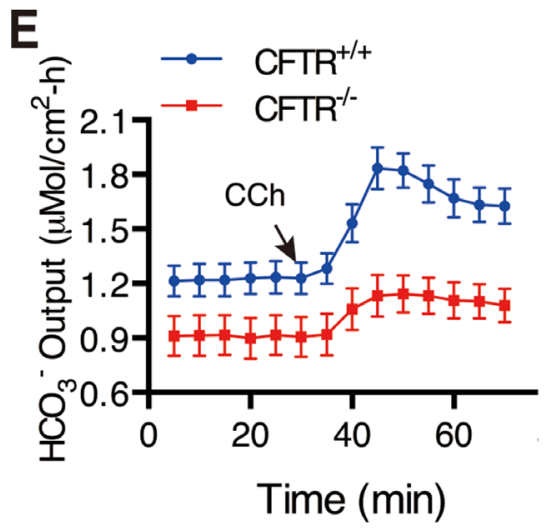

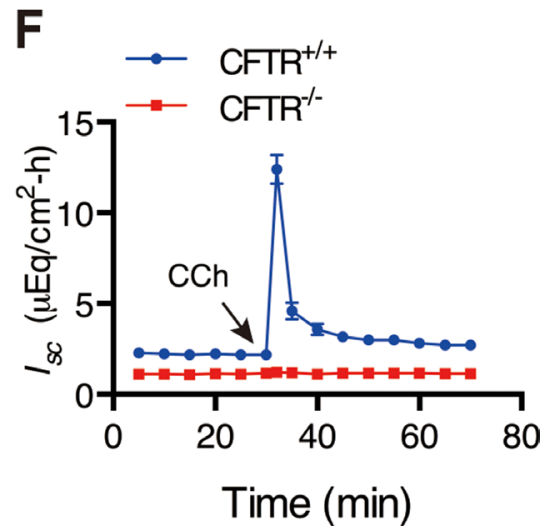

Figure 4: Role of CFTR channels in CCh-induced duodenal epithelial ion secretion. (A-B) Summary data on the effects of NFA (10 M, $n=15$ and $3 \mathrm{M}, n=6)(\mathrm{A})$ and T16Ainh-A01 (T16A, $30 \mathrm{M}, n=11)$ (B) on CCh-stimulated duodenal $I_{\mathrm{sc}}$ peaks after mucosal addition. (C) Representative of the time course of CCh-stimulated duodenal $I_{\text {sc }}$ with or without mucosal addition of CFTR inh $-172\left(\mathrm{CFTR}_{\text {inh }}\right.$, $3 \mathrm{M})$. (D) Summary on the effect of CFTR $-172\left(\right.$ CFTR $\left._{\mathrm{inh}}, 3 \mathrm{M}\right)$ on CCh-stimulated duodenal $I_{\mathrm{sc}}$ peak $(n=9)$. (E-F) Summary on the time courses of CCh-stimulated duodenal $\mathrm{HCO}_{3^{-}}$secretion $(\mathrm{E})$ and $I_{\mathrm{sc}}(\mathrm{F})$ in $\mathrm{CFTR}+/+$ or $\mathrm{CFTR}^{-/}$mice $(n=6)$. Results are presented as mean SE. NS, no significant differences, ${ }^{* *} P<0.01 v$ s. control. 
A

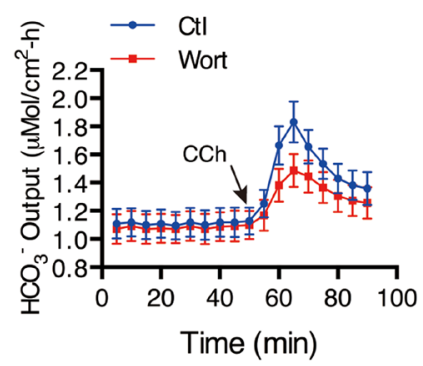

C
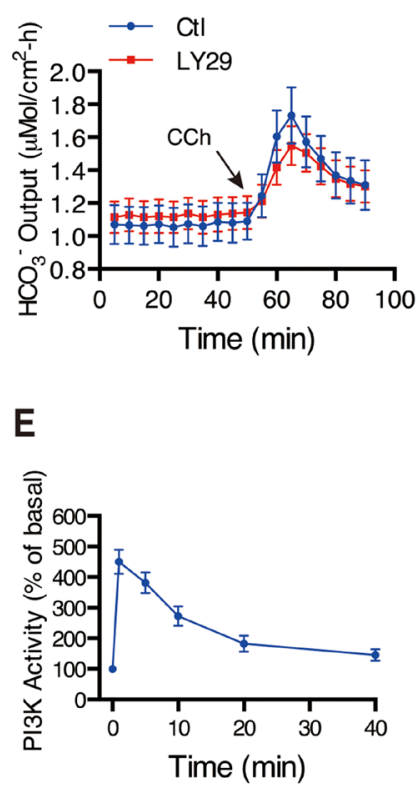

B

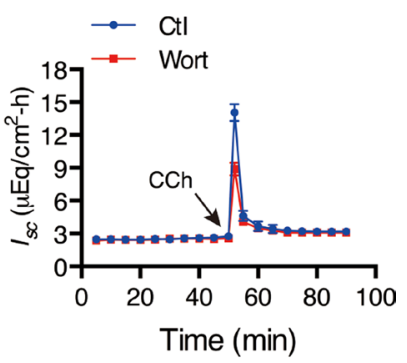

D
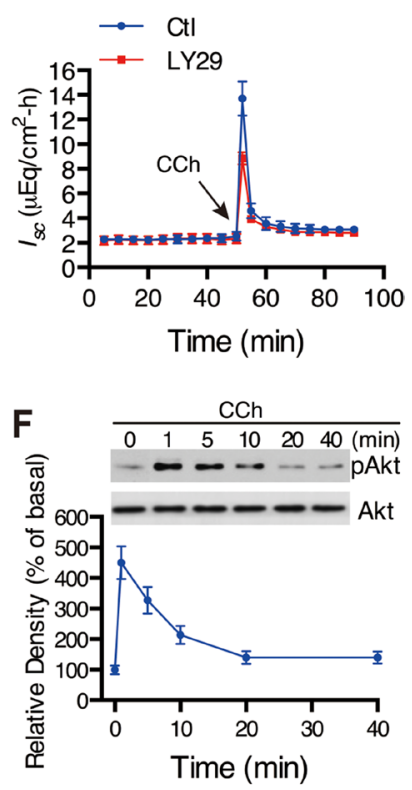

G

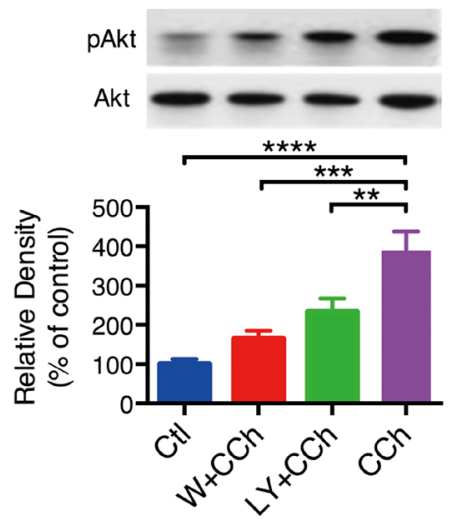

Figure 5: Involvements of PI3K/Akt in CCh-induced duodenal ion secretion. (A-B) Summary on the time courses of CChstimulated duodenal $\mathrm{HCO}_{3^{-}}$secretion (A) and $I_{\mathrm{sc}}$ (B) with or without wortmannin (Wort, $\left.0.1 \mathrm{M}\right)$ added to serosal side $(n=7)$. $(\mathbf{C}-\mathbf{D})$ Summary on the time courses of CCh-stimulated duodenal $\mathrm{HCO}_{3}$ secretion (A) and $I_{\text {sc }}$ (B) with or without LY294002 (LY29, $2 \mathrm{M}$ ) added to serosal side $(n=7)$. (E) Time course of CCh-stimulated duodenal mucosal epithelial PI3K activity. Murine duodenal mucosa was treated for various periods of time with $\mathrm{CCh}(10 \mathrm{M})$. Mucosal extract was immunoprecipitated with anti-PI3K P85 antibody in vitro $(n=$ 4). (F) Time course of CCh-stimulated phosphorylation of Akt. Duodenal mucosae were incubated with $\mathrm{CCh}$ for the indicated times and were subjected to Western blot analysis. Top: blots showing Akt phosphorylation. Data are from a single experiment representative of 4 experiments. Bottom: Summary results are expressed as the percentage of basal values $(n=4)$. (G) Effects of wortmannin $(\mathrm{W}, 0.1 \mathrm{M})$, or LY294002 (LY, 2 M) on CCh-stimulated phosphorylation of Akt of murine duodenal mucosa. The summary results are expressed as the percentage of controls $(n=4)$. Results are presented as mean SE. ${ }^{* *} p<0.01,{ }^{* * *} P<0.001,{ }^{* * * *} P<0.0001$ vs. control. 
stimulated translocation and phosphorylation of CFTR channels in duodenal epithelial cells.

We first examined the effect of $\mathrm{CCh}$ on translocation of CFTR to the surface of duodenal villus cells in mice. As shown in Figure 6A, CFTR proteins were mainly located in the cytoplasmic compartments of duodenal villus cells in control (a1 in Figure 6A). However, after administration of CCh $(100 \mu \mathrm{M})$ for $5 \mathrm{~min}$, CFTR proteins were prominent along the plasma membranes of villus cells (a2 in Figure 6A), indicating $\mathrm{Ca}^{2+}$ signaling-stimulated trafficking of CFTR proteins to the plasma membranes of villus cells. Wortmannin $(0.1 \mu \mathrm{M})$ markedly inhibited CCh-induced CFTR redistribution from the cytoplasmic compartments to the plasma membranes (a3 in Figure 6A). After quantifying the ratio of CFTR fluorescence intensity in plasma membrane and cytoplasm, $\mathrm{CCh}$ increased the ratio by 4.4-fold compared with control, but wortmannin decreased $\mathrm{CCh}$-increased ratio by $41 \%$ (Figure 6B). Therefore, CCh-induced $\mathrm{Ca}^{2+}$ signaling stimulates translocationof CFTR to the surface of duodenal villus cells, in which PI3K plays a critical role.

We further examined the role of CCh-induced $\mathrm{Ca}^{2+}$ signaling in CFTR phosphorylation of mouse duodenal epithelia. The upper panel in Figure 6C illustrates a representative autoradiograph of CFTR phosphorylation after pretreatment with $\mathrm{CCh}$ and $\mathrm{CCh}$ plus either wortmannin $(0.1 \mu \mathrm{M})$ or LY294002 $(20 \mu \mathrm{M})$. The lower panel in Figure 6C summarizes the intensity of CFTR phosphorylation. Compared with control, $\mathrm{CCh}$ increased CFTR phosphorylation by 4.6 -fold. However, wortmannin and LY294002 inhibited CCh-induced CFTR phosphorylation by $46 \%$ and $43 \%$, respectively. Therefore, these data not only confirm CCh-induced $\mathrm{Ca}^{2+}$ signaling stimulates CFTR phosphorylation, but also indicate the important role of PI3K in the activation of duodenal epithelial CFTR channels.

\section{DISCUSSION AND CONCLUSIONS}

Although it is known for the importance of $\mathrm{Ca}^{2+}$ signaling in ion transports in the salivary gland, pancreatic ducts and colonic epithelia, the detailed role of $\left[\mathrm{Ca}^{2+}\right]$ cyt in the modulation of samll intestinal epithelial ion secretion and the underlying molecular mechanisms are not fully understood. In the present study, using native mouse duodenal epithelium with preserved polarity we reveal that: 1) activation of muscarinic receptors induces epithelial ion secretion via a pure $\mathrm{Ca}^{2+}$ signaling rather than a combination to cAMP/PKA pathway; 2) muscarinic receptor-induced $\mathrm{Ca}^{2+}$ signaling is via the SOCE mechanism on the serosal side of epithelial cells; 3) CRAC/Orai channels may serve as SOCE mechanism to mediate $\mathrm{Ca}^{2+}$-dependent ion secretion; 4) $\mathrm{Ca}^{2+}$ signaling regulates ion secretion via a novel PI3K/Akt-mediated activity of CFTR channels. Therefore, our results not only indicate that $\mathrm{Ca}^{2+}$ signaling per se plays a critical role in the regulation of small intestinal ion transports, but also provide a novel insight into the molecular mechanisms of $\mathrm{Ca}^{2+}$-mediated epithelial ion secretion.

$\left[\mathrm{Ca}^{2+}\right]_{\text {cyt }}$ acts as an universal second messenger to regulate many different cellular functions in a variety of cells [31], including epithelial cells, and $\left[\mathrm{Ca}^{2+}\right]_{\mathrm{cyt}}$ is considered as an important regulator of intestinal ion transports $[2,32$, 33]. In excitable cells, $\mathrm{Ca}^{2+}$ entry is mainly mediated via voltage-gated $\mathrm{Ca}^{2+}$ channels (VGCC). However, little is known about $\mathrm{Ca}^{2+}$ entry pathways in nonexcitable intestinal epithelial cells, since they may not express functional VGCC [34]. There was essentially less information available about the specific $\mathrm{Ca}^{2+}$ entry pathways existing in native small intestinal epithelium to mediate ion secretion. Therefore, in the present study, we firstly confirmed the critical role of pure $\mathrm{Ca}^{2+}$ signaling in duodenal ion secretion. Since intestinal epithelium is polarized in nature, we then revealed that $\mathrm{CCh}$-induced external $\mathrm{Ca}^{2+}$ entry is just from serosal side of duodenal epithelial cells rather than from the lumen. We also examined the potential molecular candidate of SOCE mechanisms in regulating duodenal ion transport, and identified CRAC/Orai channels as the most likely molecular candidate, which is partially consistent with a previous report that STIM1/Orai may regulate $\mathrm{Ca}^{2+}$ influx across the apical and basolateral membrane in rat colonic epithelium [12]. However, it is currently unknown why $\mathrm{CCh}$ induces $\mathrm{Ca}^{2+}$ influx across the basolateral membrane only in mouse duodenal epithelium, which needs further investigation.

cAMP and $\left[\mathrm{Ca}^{2+}\right]_{\text {cyt }}$ signaling are pleiotropic primary second messengers that regulate all secretory epithelia functions. Since cAMP pathway has been extensively studied, it is questioned if pure $\mathrm{Ca}^{2+}$ signaling is critical for intestinal ion secretion. Moreover, mutual regulation of cAMP and $\mathrm{Ca}^{2+}$ signaling is referred to as crosstalk, while integration of their effects can result in an additive or synergistic physiological response [35]. So far, the synergism of cAMP and $\mathrm{Ca}^{2+}$ signaling has been demonstrated for ion secretion in salivary gland and pancreatic ducts [36], but not in small intestinal epithelium. The available findings suggest that the IP3R binding protein released with inositol 1,4,5-trisphosphate (IRBIT) protein is a central component of the mechanism mediating the synergism between cAMP and $\mathrm{Ca}^{2+}$ by functioning as a third messenger that translocates between the $\mathrm{IP}_{3} \mathrm{R}$ and target proteins $[37,38]$. Both cAMP and PKA are critical stimulators for this synergistic process. However, in the present study, although we observed the synergism of cAMP- and $\mathrm{Ca}^{2+}$-mediated ion secretion, we did not detect any change in cAMP concentrations induced by $\mathrm{CCh}$ in duodenal epithelium. Furthermore, the synergistic effect was not affected by PKA inhibition. Therefore, our data indicate that $\mathrm{CCh}$ induced $\mathrm{Ca}^{2+}$ dependent but cAMP/PKA-independent ion secretionin duodenal epithelium, confirming the critical role of pure $\mathrm{Ca}^{2+}$ signaling in this process. 
A

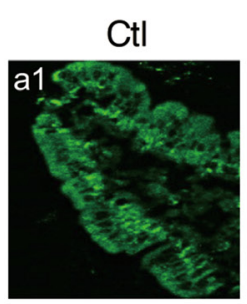

B

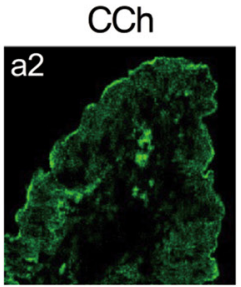

\section{C}
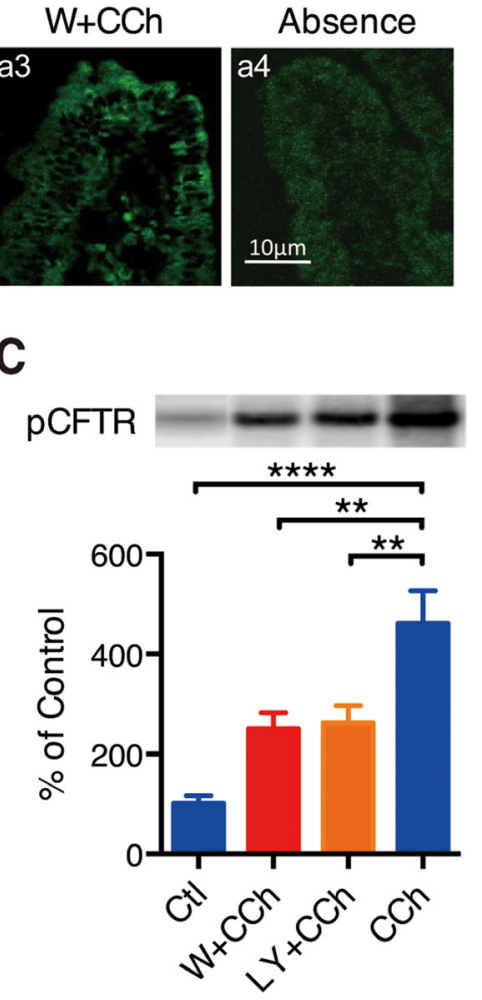

D
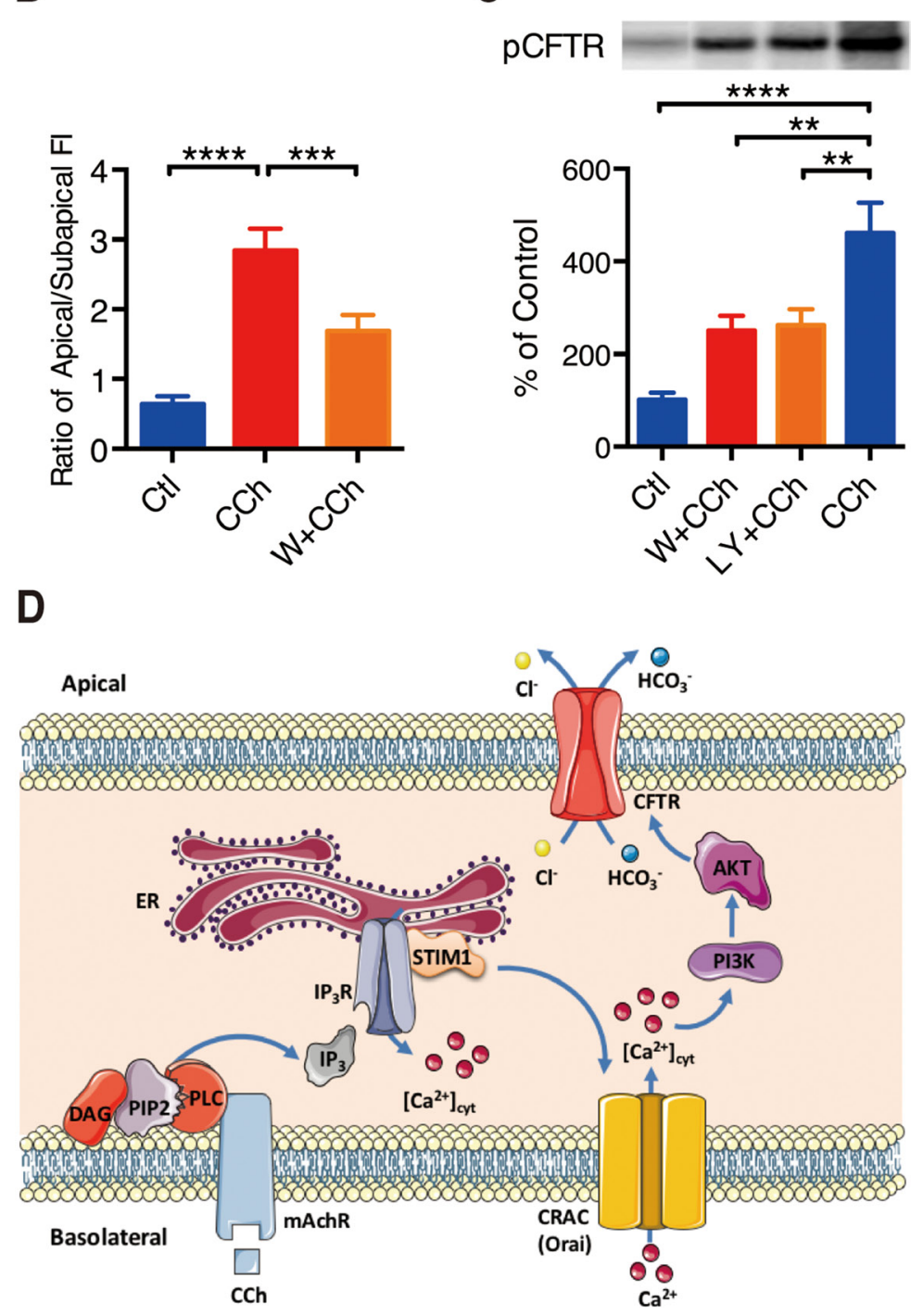

Figure 6: PI3K/Akt in CCh-mediated phosphorylation and translocation of CFTR channels. (A) Representative showing effect of wortmannin (W, 0.1 M) on CCh-induced CFTR trafficking to the plasma membranes of duodenal villus cells. a1: distribution of CFTR in unstimulated control vehicle-treated duodenal villus cells. a2: distribution of CFTR in duodenal villus cells at 5 min after stimulation using CCh (100 M). a3: effect of wortmannin (W, 0.1 M) on CCh-induced distribution of CFTR in duodenal villus cells. $a 4$ : control with CCh in the absence of primary anti-CFTR antibody. Magnification, 600; calibration bar, $10 \mathrm{~m}$. (B) Summary data on the ratio of plasma membrane to cytoplasm CFTR fluorescence intensity (FI). Values are mean SE ( $n=120$ cells in 4 animals, 30 cells from each tissue). (C) Summary data on the effects of wortmannin (W, 0.1 M), LY294002 (LY, 2 M) on CCh-induced CFTR phosphorylation in duodenal mucosal epithelial cells. Top: autoradiographs showing 32P-phosphorylated CFTR. Data are from a single representative experiment of 4 experiments in each series. Bottom: The summary results are expressed as a percentage of controls. Values are mean $\mathrm{SE}(n=4)$. (D) Schematic diagram depicting the proposed mechanisms of $\mathrm{Ca}^{2+}$-mediated duodenal epithelial $\mathrm{HCO}_{3^{-}}$and $\mathrm{Cl}^{-}$secretion mediated by $\mathrm{CCh}$. 
We further elucidated the underlying molecular mechanisms by how $\mathrm{Ca}^{2+}$ signaling regulates duodenal ion secretion. Although $\mathrm{CaCC}$ is critical for $\mathrm{Ca}^{2+}$-mediated ion secretion in other epithelial tissues, we did not detect their functional expression in duodenal epithelium. Therefore, the present study focused on the CFTR-mediated ion secretion since we underscored the importance of these channels in the process. Growing evidence suggests that $\mathrm{Ca}^{2+}$ signaling can stimulate CFTR channels by activating $\mathrm{Ca}^{2+}$-dependent adenylyl cyclase via cAMP/PKA pathway. However, our study ruled out this possibility in the duodenum because cAMP/PKA pathway is not involved in this $\mathrm{CCh}$-induced $\mathrm{Ca}^{2+}$-mediatedion secretion. Furthermore, we revealed that $\mathrm{Ca}^{2+}$ signaling regulates duodenal ion secretion via a novel PI3K/Akt-mediated activity of CFTR channels.

Compelling evidence shows that cAMP-induced epithelial ion secretion is regulated mainly through PKAmediated CFTR phosphorylation, which in turn stimulates both channel gating and trafficking to apical plasma membrane of polarized cells, leading to the increase of ion secretion $[39,40]$. Previous studies reported the requirement of $\mathrm{PI} 3 \mathrm{~K}$ for glucagon-induced trafficking of aquaporin-8 [41] and angiotensin II-induced trafficking of $\mathrm{Na}^{+} / \mathrm{H}^{+}$exchanger to plasma membrane, indicating that $\mathrm{PI} 3 \mathrm{~K}$ is involved in exocytotic insertion of proteins into plasma membrane [42]. Therefore, we further examined whether intracellular trafficking of CFTR is stimulated by $\mathrm{CCh}$-induced $\mathrm{Ca}^{2+}$ signaling. Indeed, $\mathrm{CCh}$ stimulated CFTR trafficking to the plasma membranes of villus cells in duodenal epithelia, which was significantly inhibited by PI3K inhibitors. Together, our results obtained from functional, biochemical, and morphological studies have demonstrated the importance of PI3K in the regulation of CCh-mediated duodenal epithelial CFTR channel activity. To provide direct evidence for the role of PI3K in the regulation of duodenal epithelial CFTR function, we further examined PI3K activity and phosphorylation of Akt, a downstream effector of PI3K, in murine duodenal epithelium. Our results indicate that $\mathrm{CCh}$ induced $\mathrm{Ca}^{2+}$ signal activates PI3K/Akt in duodenal epithelium.

In conclusion, we underscored the critical role of $\mathrm{Ca}^{2+}$ signaling in small intestinal epithelial ion secretion via the SOCE mechanism on the serosal side of epithelial cells. We identified that CRAC/Orai channels may serve as SOCE mechanism to mediate $\mathrm{Ca}^{2+}$-dependent epithelial ion secretion. We also demonstrated the molecular mechanisms of $\mathrm{Ca}^{2+}$ signaling in CFTR-mediated ion secretion via a novel $\mathrm{PI} 3 \mathrm{~K} / \mathrm{Akt}$ pathway rather than the well-known cAMP/PKA pathway. A scheme summarizes our findings in Figure 6D. A full understanding of $\mathrm{Ca}^{2+}$ mediated intestinal epithelial $\mathrm{Cl}^{-}$and $\mathrm{HCO}_{3}^{-}$secretion and the precise modulatory mechanisms of this process will greatly enhance our knowledge about ion transports in GI tract. Our findings suggest new perspectives for potential drug targets to protect the upper GI tract through promoting epithelial $\mathrm{HCO}_{3}^{-}$secretion and to control intestinal liquid homeostasis through modulating epithelial $\mathrm{Cl}^{-}$secretion.

\section{MATERIALS AND METHODS}

\section{Cell culture}

The HT-29 cell lines used in this work were obtained from the American Type Culture Collection (Rockville, MD) and were cultured at $37^{\circ} \mathrm{C}$ under $5 \% \mathrm{CO}_{2}$ in RPMI 1640 medium supplemented with antibiotics $(100 \mathrm{U} / \mathrm{ml}$ of penicillin and $100 \mu \mathrm{g} / \mathrm{ml}$ of streptomycin) and $10 \%$ heatinactivated fetal bovine serum. After the cells had grown to confluence, they were replated onto $12-\mathrm{mm}$ round coverslips (Warner Instruments Inc., Hamden, CT) and incubated for at least $24 \mathrm{~h}$ before use for cytosolic $\mathrm{Ca}^{2+}$ concentration $\left(\left[\mathrm{Ca}^{2+}\right]_{\text {cyt }}\right)$.

\section{Animal preparation}

All studies were approved by Committees on Investigations Involving Animals in Xinqiao Hospital of Third Military Medical University, China and the University of California, San Diego. Experiments were performed with on 6-12 wk male Harlan C-57 black mice; homozygous CFTR knockout $\left(\mathrm{CFTR}^{-/}\right)$mice and their wild-type littermates $\left(\mathrm{CFTR}^{+/+}\right)$, which were established as described previously [43].

\section{Ussing chamber experiments}

Ussing chamber experiments were performed as previously described [44]. The duodenal tissue from each animal was stripped of seromuscular layers, divided, and examined in four chambers (window area, $0.1 \mathrm{~cm}^{2}$ ). Experiments were performed under continuous shortcircuited conditions (Voltage-Current Clamp, VCC MC6; Physiologic Instruments, San Diego, CA), and luminal $\mathrm{pH}$ was maintained at 7.40 by the continuous infusion of 0.5 $\mathrm{mM} \mathrm{HCl}$ under the automatic control of a $\mathrm{pH}$-stat system (PHM290, pH-Stat controller; Radiometer Copenhagen). The volume of the titrant infused per unit time was used to quantitate $\mathrm{HCO}_{3}{ }^{-}$secretion. These measurements were recorded at 5-min intervals. The rate of luminal $\mathrm{HCO}_{3}$ secretion is expressed as micromoles per centimeter squared per hour. Transepithelial short-circuit current $\left(I_{s c}\right.$; reported as $\mu \mathrm{A}$ or eq $\mathrm{cm}^{-2} \mathrm{~h}^{-1}$ ) was measured via an automatic voltage clamp. After a 15-30 min measurement of basal parameters, inhibitors were added to the tissues for 10-20 $\mathrm{min}$, as dictated by the experimental design, followed by addition of carbachol $(100 \mu \mathrm{M})$ or forskolin $(10 \mu \mathrm{M})$ to the serosal side of tissue. 


\section{Measurement of $\left[\mathrm{Ca}^{2+}\right]_{\mathrm{cyt}}$ by digital $\mathrm{Ca}^{2+}$ imaging}

$\mathrm{Ca}^{2+}$ imaging experiments were performed as previously described [45]. HT-29 cells cultured on coverslips were loaded with $5 \mu \mathrm{M}$ Fura-2 AM (Invitrogen, NY, USA) in physiological salt solution (PSS) at $37^{\circ} \mathrm{C}$ for $50 \mathrm{~min}$ and then washed with PSS or PPS with 2-APB (Tocris Bioscience, Minneapolis, MN, USA), a CRAC channel blockers $(50 \mu \mathrm{M})$; or GSK-7975A (Tocris Bioscience, Minneapolis, MN, USA), for $30 \mathrm{~min}$. Then, cells on coverslips were placed in a standard perfusion chamber on the stage of an inverted fluorescence microscope (Nikon, Japan). For the $\mathrm{Ca}^{2+}$-free solution, $\mathrm{Ca}^{2+}$ was omitted and $0.5 \mathrm{mM}$ EGTA was added to prevent possible $\mathrm{Ca}^{2+}$ contamination.

\section{Phosphate labeling and immunoprecipitation of CFTR}

The mice were prepared as described above. Segments of proximal duodenum $(\sim 5 \mathrm{~mm})$ opened along the mesenteric border were placed in modified buffered Ringer solution at $37^{\circ} \mathrm{C}$ gassed with $95 \% \mathrm{O}_{2}-5 \% \mathrm{CO}_{2}$ for incubation. After stabilization for $20 \mathrm{~min}, \mathrm{CCh}(100 \mu \mathrm{M})$ or control vehicle was added to the bathing solution for 5 min of incubation. When wortmannin $(0.1 \mu \mathrm{M})$ or LY294002 $(20 \mu \mathrm{M})$ was used, it was added at $30 \mathrm{~min}$ before the agents above. Phosphate labeling and immunoprecipitation of CFTR was performed as described [43]. Briefly, CFTR was immunoprecipitated from the supernatant with CFTR polyclonal antibody (CFTR H-182; Santa Cruz Biotechnology) for $1 \mathrm{~h}$ at $4^{\circ} \mathrm{C}$. The samples were centrifuged, and the supernatants were analyzed by $6 \%$ SDS-polyacrylamide gel electrophoresis (SDS- PAGE). 32P-phosphorylated CFTR was visualized by autoradiography and quantified by scintillation counting of excised bands.

\section{Immunoprecipitation of PI3K and ELISA for detection of PI3K and cAMP activity}

Segments of murine duodenum were incubated for different time points as described above. Immunoprecipitation of PI3K was performed as described [44]. PI3K activity was measured in vitro using a competitive ELISA format (Echelon Biosciences, Salt Lake City, UT) and cAMP activity was measured in vitro using Mouse/ Rat cAMP assay(FGE012B) from R\&D Systems Inc. (Minneapolis, MN, USA) according to the manufacturer's instructions. Enzyme activity was estimated by comparing the values from samples containing enzymatic reaction products to the values in the standard curve.

\section{Western blot analysis for measurement of Akt phosphorylation}

Segments of murine duodenum were incubated with $\mathrm{CCh}(100 \mu \mathrm{M})$, or control vehicle for different time points as described above. At the end of incubation, the tissue was processed as described in detection of PI3K activity above. Protein concentrations were determined using a Bradford protein assay (BioRad, Hercules, CA, USA). A total of $50 \mu \mathrm{g}$ protein aliquots were separated by SDSPAGE electrophoresis and blotted using a V3 Western Workflow system (BioRad, Hercules, CA, USA) according to the manufacturer's instructions. PVDF membranes were incubated with primary antibodies: anti-phospho-Akt S473 or anti-Akt (diluted 1:1,000; Cell Signaling) overnight at $4^{\circ} \mathrm{C}$. All results were measured by densitometry and presented as relative expression to tubulin as a reference protein.

\section{Immunohistochemistry}

Segments of murine duodenum were incubated as described above. Immunofluorescence labeling was performed as described [43]. Sections were incubated in a moist chamber overnight with primary anti-CFTR antibody (CFTR H-182, 1:50 dilution in 1\% PBS-BSA) at $4^{\circ} \mathrm{C}$, washed three times for $15 \mathrm{~min}$ each and incubated with FITC-conjugated secondary antibody (affinity purified donkey anti-rabbit IgG, 1:400 dillution in 1\% PBS-BSA), for $1 \mathrm{~h}$ at room temperature to detect CFTR staining. Confocal microscopy and images analysis of CFTR fluorescence intensities were performed as described by Ameen et al. [46, 47] using a confocal microscope (TCS SP2 AOBS; Leica, Wetzlar, Germany) equipped with image analysis software. Data were collected from an average of 30 cells in random sections labeled for CFTR (average 10 sections) from each tissue examined (4 animals in each series) and is expressed as the ratio of plasma membrane to cytoplasm fluorescence intensity.

\section{Statistics}

The data and statistical analysis comply with the recommendations on experimental design and analysis in pharmacology [48]. All results are means \pm SE. Net peaks for duodenal $\mathrm{HCO}_{3}^{-}$secretion and $I_{s c}$ refer to stimulated peak responses minus basal levels. Data were analyzed using one-way analysis of variance followed by the Newman-Keul post hoc test or, when appropriate, by the two-tailed Student's $t$-tests. $\mathrm{P}<0.05$ was considered statistically significant.

\section{Materials}

The following drugs were used: carbachol, Forskolin, wortmannin, LY294002, and rapamycin from Sigma; CFTRinh-172 from Calbiochem; [22P] orthophosphate from Amer-sham; Anti-PI3K p85 was obtained from Upstate Biotechnology; Anti-phosphoAkt S473 antibody and anti-Akt antibody were obtained from Cell Signaling; All other chemicals in solutions were obtained from Sigma and Calbiochem. 


\section{Abbreviations}

CCh: carbachol; CFTR: cystic fibrosis transmembrane conductance regulator; GI: gastrointestinal; CaCCs: $\mathrm{Ca}^{2+}$-activated $\mathrm{Cl}^{-}$channels; 2-APB: 2-aminoethoxydiphenyl borate; SOCE: storeoperated $\mathrm{Ca}^{2+}$ entry; CRAC: $\mathrm{Ca}^{2+}$ release-activated $\mathrm{Ca}^{2+}$ channels; $\mathrm{IP}_{3}$ : inositol 1,4,5-trisphoshate; $\left[\mathrm{Ca}^{2+}\right]_{\text {cyt }}$ : cytosolic $\mathrm{Ca}^{2+}$ concentration; IEC: intestinal epithelial cells; $I_{\mathrm{sc}}$ : short-circuit current; FFA: Flufenamic acid; ER: endoplasmic reticulum; NFA: niflumic acid; VGCC: voltage-gated $\mathrm{Ca}^{2+}$ channels; IRBIT: IP3R binding protein released with inositol 1,4,5-trisphosphate.

\section{Author contributions}

H.D. designed the experiments. X.Y. did the $\mathrm{Ca}^{2+}$ imaging and Elisa. G.R.W. and B.G.T. did the immunoprecipitation, Western blot and immunohistochemistry. X.Y. and F.L.Z. did the Ussing chamber experiments. H.X.W. and J.L.H. did the cell culture. X.Y. and H.D. wrote the manuscript. H.D. and S.M.Y. revised and finalized the manuscript. All authors reviewed the manuscript.

\section{CONFLICTS OF INTEREST}

The authors declare no conflicts of interest.

\section{FUNDING}

These studies were supported by research grants from the National Key Research and Development Program of China (No. 2016YFC1302200 to HD) and the National Natural Science Foundation of China (No. 81570477 and No. 31371167 to HD).

\section{REFERENCES}

1. Flemstrom G, Garner A. Gastroduodenal HCO3(-) transport: characteristics and proposed role in acidity regulation and mucosal protection. Am J Physiol. 1982; 242:G183-193.

2. Jung J, Lee MG. Role of calcium signaling in epithelial bicarbonate secretion. Cell Calcium. 2014; 55:376-384.

3. Xie R, Dong X, Wong C, Vallon V, Tang B, Sun J, Yang $\mathrm{S}$, Dong H. Molecular mechanisms of calcium-sensing receptor-mediated calcium signaling in the modulation of epithelial ion transport and bicarbonate secretion. J Biol Chem. 2014; 289:34642-34653.

4. Putney JW Jr. Recent breakthroughs in the molecular mechanism of capacitative calcium entry (with thoughts on how we got here). Cell Calcium. 2007; 42:103-110.

5. Putney JW Jr. A model for receptor-regulated calcium entry. Cell Calcium. 1986; 7:1-12.
6. Putney JW Jr. Capacitative calcium entry revisited. Cell Calcium. 1990; 11:611-624.

7. Hoth M, Penner R. Depletion of intracellular calcium stores activates a calcium current in mast cells. Nature. 1992; 355:353-356.

8. Hoth M, Penner R. Calcium release-activated calcium current in rat mast cells. J Physiol. 1993; 465:359-386.

9. Mignen O, Thompson JL, Yule DI, Shuttleworth TJ. Agonist activation of arachidonate-regulated $\mathrm{Ca} 2+$-selective (ARC) channels in murine parotid and pancreatic acinar cells. J Physiol. 2005; 564:791-801.

10. Molnar T, Yarishkin O, Iuso A, Barabas P, Jones B, Marc RE, Phuong TT, Krizaj D. Store-Operated Calcium Entry in Muller Glia Is Controlled by Synergistic Activation of TRPC and Orai Channels. J Neurosci. 2016; 36:3184-3198.

11. Rao JN, Rathor N, Zou T, Liu L, Xiao L, Yu TX, Cui YH, Wang JY. STIM1 translocation to the plasma membrane enhances intestinal epithelial restitution by inducing TRPC1-mediated $\mathrm{Ca} 2+$ signaling after wounding. Am J Physiol Cell Physiol. 2010; 299:C579-588.

12. Onodera K, Pouokam E, Diener M. STIM1-regulated Ca2+ influx across the apical and the basolateral membrane in colonic epithelium. J Membr Biol. 2013; 246:271-285.

13. Lefkimmiatis K, Srikanthan M, Maiellaro I, Moyer MP, Curci S, Hofer AM. Store-operated cyclic AMP signalling mediated by STIM1. Nat Cell Biol. 2009; 11:433-442.

14. Seidler U, Blumenstein I, Kretz A, Viellard-Baron D, Rossmann H, Colledge WH, Evans M, Ratcliff R, Gregor M. A functional CFTR protein is required for mouse intestinal cAMP-, cGMP- and $\mathrm{Ca}(2+)$-dependent HCO3secretion. J Physiol. 1997; 505:411-423.

15. Bradbury NA. Intracellular CFTR: localization and function. Physiol Rev. 1999; 79:S175-191.

16. Sheppard DN, Welsh MJ. Structure and function of the CFTR chloride channel. Physiol Rev. 1999; 79:S23-45.

17. Banks MR, Farthing MJ. Fluid and electrolyte transport in the small intestine. Curr Opin Gastroenterol. 2002; 18:176-181.

18. Chao AC, de Sauvage FJ, Dong YJ, Wagner JA, Goeddel DV, Gardner P. Activation of intestinal CFTR Cl- channel by heat-stable enterotoxin and guanylin via cAMPdependent protein kinase. EMBO J. 1994; 13:1065-1072.

19. Kaji I, Akiba Y, Kaunitz JD. Digestive physiology of the pig symposium: involvement of gut chemosensing in the regulation of mucosal barrier function and defense mechanisms. J Anim Sci. 2013; 91:1957-1962.

20. Lindqvist SM, Sharp P, Johnson IT, Satoh Y, Williams MR. Acetylcholine-induced calcium signaling along the rat colonic crypt axis. Gastroenterology. 1998; 115:1131-1143.

21. Mei FC, Qiao J, Tsygankova OM, Meinkoth JL, Quilliam LA, Cheng X. Differential signaling of cyclic AMP: opposing effects of exchange protein directly activated by cyclic AMP and cAMP-dependent protein kinase on protein kinase B activation. J Biol Chem. 2002; 277:11497-11504. 
22. Perego S, Del Favero E, De Luca P, Dal Piaz F, Fiorilli A, Cantu L, Ferraretto A. Calcium bioaccessibility and uptake by human intestinal like cells following in vitro digestion of casein phosphopeptide-calcium aggregates. Food Funct. 2015; 6:1796-1807.

23. Dong X, Ko KH, Chow J, Tuo B, Barrett KE, Dong H. Expression of acid-sensing ion channels in intestinal epithelial cells and their role in the regulation of duodenal mucosal bicarbonate secretion. Acta Physiol (Oxf). 2011; 201:97-107.

24. Bajwa PJ, Lee JW, Straus DS, Lytle C. Activation of PPARgamma by rosiglitazone attenuates intestinal Clsecretion. Am J Physiol Gastrointest Liver Physiol. 2009; 297:G82-89.

25. Himmerkus N, Vassen V, Sievers B, Goerke B, Shan Q, Harder J, Schroder JM, Bleich M. Human beta-defensin-2 increases cholinergic response in colon epithelium. Pflugers Arch. 2010; 460:177-186.

26. De La Fuente R, Namkung W, Mills A, Verkman AS. Smallmolecule screen identifies inhibitors of a human intestinal calcium-activated chloride channel. Mol Pharmacol. 2008; 73:758-768.

27. Ma T, Thiagarajah JR, Yang H, Sonawane ND, Folli C, Galietta LJ, Verkman AS. Thiazolidinone CFTR inhibitor identified by high-throughput screening blocks cholera toxin-induced intestinal fluid secretion. J Clin Invest. 2002; 110:1651-1658.

28. Billet A, Hanrahan JW. The secret life of CFTR as a calciumactivated chloride channel. J Physiol. 2013; 591:5273-5278.

29. Powis G, Bonjouklian R, Berggren MM, Gallegos A, Abraham R, Ashendel C, Zalkow L, Matter WF, Dodge J, Grindey G, Vlahos CJ. Wortmannin, a potent and selective inhibitor of phosphatidylinositol-3-kinase. Cancer Res. 1994; 54:2419-2423.

30. Vlahos CJ, Matter WF, Hui KY, Brown RF. A specific inhibitor of phosphatidylinositol 3-kinase, 2-(4-morpholinyl)-8-phenyl-4H-1-benzopyran-4-one (LY294002). J Biol Chem. 1994; 269:5241-5248.

31. Berridge MJ, Bootman MD, Roderick HL. Calcium signalling: dynamics, homeostasis and remodelling. Nat Rev Mol Cell Biol. 2003; 4:517-529.

32. Chew CS, Safsten B, Flemstrom G. Calcium signaling in cultured human and rat duodenal enterocytes. Am J Physiol. 1998; 275:G296-304.

33. Flemstrom G, Isenberg JI. Gastroduodenal mucosal alkaline secretion and mucosal protection. News Physiol Sci. 2001; $16: 23-28$.

34. Parekh AB, Penner R. Store depletion and calcium influx. Physiol Rev. 1997; 77:901-930.

35. Ahuja M, Jha A, Maleth J, Park S, Muallem S. cAMP, Ca(2) $(+)$ signaling in secretory epithelia: crosstalk and synergism. Cell Calcium. 2014; 55:385-393.

36. Park S, Shcheynikov N, Hong JH, Zheng C, Suh SH, Kawaai K, Ando H, Mizutani A, Abe T, Kiyonari H,
Seki G, Yule D, Mikoshiba K, Muallem S. Irbit mediates synergy between $\mathrm{ca}(2+)$ and cAMP signaling pathways during epithelial transport in mice. Gastroenterology. 2013; 145:232-241.

37. Ando H, Kawaai K, Mikoshiba K. IRBIT: a regulator of ion channels and ion transporters. Biochim Biophys Acta. 2014; 1843:2195-2204.

38. Ando H, Mizutani A, Kiefer H, Tsuzurugi D, Michikawa T, Mikoshiba K. IRBIT suppresses IP3 receptor activity by competing with IP3 for the common binding site on the IP3 receptor. Mol Cell. 2006; 22:795-806.

39. Bertrand CA, Frizzell RA. The role of regulated CFTR trafficking in epithelial secretion. Am J Physiol Cell Physiol. 2003; 285:C1-18.

40. Guggino WB, Stanton BA. New insights into cystic fibrosis: molecular switches that regulate CFTR. Nat Rev Mol Cell Biol. 2006; 7:426-436.

41. Gradilone SA, Carreras FI, Lehmann GL, Marinelli RA. Phosphoinositide 3-kinase is involved in the glucagoninduced translocation of aquaporin- 8 to hepatocyte plasma membrane. Biol Cell. 2005; 97:831-836.

42. du Cheyron D, Chalumeau C, Defontaine N, Klein C, Kellermann O, Paillard M, Poggioli J. Angiotensin II stimulates NHE3 activity by exocytic insertion of the transporter: role of PI 3-kinase. Kidney Int. 2003; 64:939-949.

43. Tuo B, Wen G, Zhang Y, Liu X, Wang X, Liu X, Dong H. Involvement of phosphatidylinositol 3-kinase in cAMPand cGMP-induced duodenal epithelial CFTR activation in mice. Am J Physiol Cell Physiol. 2009; 297:C503-515.

44. Tuo B, Wen G, Wang X, Xu J, Xie R, Liu X, Dong H. Estrogen potentiates prostaglandin E-stimulated duodenal mucosal $\mathrm{HCO}(3)(-)$ secretion in mice. Am J Physiol Endocrinol Metab. 2012; 303:E111-121.

45. Wan H, Xie R, Xu J, He J, Tang B, Liu Q, Wang S, Guo Y, Yang X, Dong TX, Carethers JM, Yang S, Dong H. Antiproliferative Effects of Nucleotides on Gastric Cancer via a Novel P2Y6/SOCE/Ca2+/beta-catenin Pathway. Sci Rep. 2017; 7:2459.

46. Ameen NA, Martensson B, Bourguinon L, Marino C, Isenberg J, McLaughlin GE. CFTR channel insertion to the apical surface in rat duodenal villus epithelial cells is upregulated by VIP in vivo. J Cell Sci. 1999; 112:887-894.

47. Ameen NA, Marino C, Salas PJ. cAMP-dependent exocytosis and vesicle traffic regulate CFTR and fluid transport in rat jejunum in vivo. Am J Physiol Cell Physiol. 2003; 284:C429-438.

48. Curtis MJ, Bond RA, Spina D, Ahluwalia A, Alexander SP, Giembycz MA, Gilchrist A, Hoyer D, Insel PA, Izzo AA, Lawrence AJ, MacEwan DJ, Moon LD, et al. Experimental design and analysis and their reporting: new guidance for publication in BJP. Br J Pharmacol. 2015; 172:3461-3471. 